\title{
Genetic Similarities of Escherichia Coli Isolated from Different Substrates of the Broiler Production Chain
}

\section{-Author(s)}

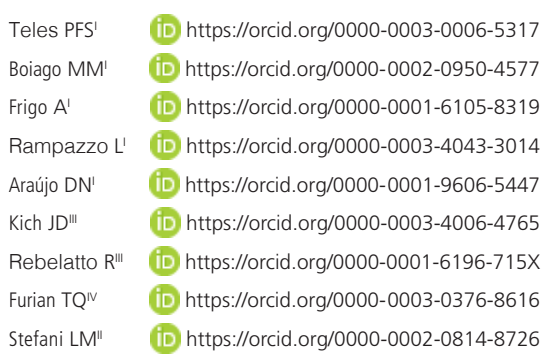

Graduate Program in Animal Science Universidade do Estado de Santa Catarina (UDESC-Oeste), Chapecó, SC, Brazil.

Universidade do Estado de Santa Catarina (UDESC), Florianópolis, SC, Brazil.

III Empresa Brasileira de Pesquisa Agropecuária (EMBRAPA), Concórdia, SC, Brazil.

v Universidade Federal do Rio Grande do Sul (UFRGS), Porto Alegre, RS, Brazil.

\section{ABSTRACT}

Brazil is the largest exporter of chicken meat and poultry farming is one of the most important productive segments, despite major losses due to the bacterium Escherichia coli, which is also a zoonotic microorganism. The objetive of this study was to isolate $E$. coli and to evaluate its transmissibility potential from the field to chicken meat using the Pulsed Field Gel Electrophoresis (PFGE) technique. Environmental samples (poultry litter, soil and water) were collected from broiler farms located in the South of Brazil where the majority of the Brazilian poultry production occurs. In addition, chicken meat (gizzard, heart, drumette and tulip) samples were collected from local supermarkets. As results, $47.36 \%$ of the samples were positives for $E$. coli. Furthermore, 10 pairs of clones of $E$. coli were found always in the same substrate (two waterwater pairs; three soil-soil pairs and five meat-meat pairs) using PFGE. These findings suggest that certain strains of $E$. coli may have habitat preferences, making the transfer from one substrate type to another more difficult to occur. Moreover, since no clones were found between environmental samples and chicken meat, it is possible to imply a low risk of $E$. coli transmissibility throughout the chicken meat production chain.

\section{INTRODUCTION}

Poultry farming is one of the most important productive segments in Brazil, placing the country as the second largest producer and first exporter of chicken meat in the world. In 2017 alone, national production was 13.1 million tons of chicken meat, of which 4.32 million tons were exported (ABPA 2018).

Escherichia coli is a well-known studied microorganism frequently isolated in clinical microbiology laboratories (Silva \& Neufeld 2006). It is responsible for invaluable economic losses in farm animals, including poultry, and represents a risk to human health (Camargo \& Suffredini 2015). It may cause intestinal disorders (diarrhea), although most strains are not pathogenic (Smith 2010).

One of the molecular biology techniques considered the gold standard for epidemiological research in microbiology is the Pulsed Field Gel Electrophoresis (PFGE), in which, using a restriction enzyme, $100 \%$ of the genetic material is evaluated (Magalhães et al. 2005).

Rwego et al. (2008) claim that we will only have rational interventions to safeguard humans and animals when, in fact, we understand the ecological and behavioral factors that influence the transmission of pathogens between species. Thus, the objective of this study was to isolate $E$. coli and to evaluate the transmissibility potential from poultry farms to chicken meat using the PFGE technique. 


\section{MATERIALS AND METHODS}

\section{Environmental sampling and bacterial isolation}

Between March ${ }^{\text {th }} 26$ and May $1^{\text {st }}$ of 2018, 171 samples were collected from 57 poultry farms located in the West part of Santa Catarina State, Brazil, integrated to the same poultry company and under the same production regime. Samples were collected from the environment (poultry litter, water and soil) being one sample of each point from every property. Soil samples were collected five $\mathrm{cm}$ bellow surface and close to the biosecurity area in a pool of three different locations. Litter samples were collected in a pool of three places inside the poultry house containing fresh feces and litter. Water sampling was carried out directly at the storage location or after three seconds of running (in case of tap water). All samples were collected using sterile bags (soil and litter) and flasks (water), being transported under refrigeration to the laboratory of the University of Santa Catarina State.

Escherichia coli isolation was performed according to the technique of Quinn et al. (2005), where samples were incubated in lactose broth at $37 \pm 10^{\circ} \mathrm{C}$ for 24 hours. They were then seeded in petri dishes containing Methylene Blue Eosin Agar (EMB LEVINE KASVI-K25-610019) and incubated at $37 \pm 1^{\circ} \mathrm{C}$ for 24 hours. When present, one green metallic colony from each sample was individually inoculated into Tryptone Soya Agar (TSA) incubated at $37 \pm 1^{\circ} \mathrm{C}$ for 24 hours and subsequently stored at $-20^{\circ} \mathrm{C}$ for further testing.

\section{Meat sampling and bacterial isolation}

Meat samples $(n=57)$ were collected in retail markets between May and June of 2018, including gizzard, heart, drumstick (drumette) and half of the wing (tulip) in natura, frozen and already packed. All samples were purchased from the same slaughterhouse that processed birds originated of sampled farms of this study. These samples were refrigerated and transported to the laboratory for $E$. coli isolation at the University of Santa Catarina State as recommended by the protocol of Downes \& Ito (2001).

\section{Pulsed Field Gel Eletrophoresis}

The PFGE technique was performed according to Ribot et al. (2006) and the Center for Disease Control and Prevention (CDC, Atlanta, GA) using the OneDay (24-28 h) Standardized Laboratory Protocol for Molecular Subtyping of E. coli O157:H7, nontyphoidal Salmonella serotypes, and Shigella sonnei by Pulsed Field Gel Electrophoresis (CDC 2017) with minor adaptations to one of the laboratories of the Brazilian Agricultural Research Corporation (Embrapa) in Concórdia, Santa Catarina State. Briefly, the bacterial suspension was soaked in agarose, lysed, washed and digested with restriction enzyme Xbal (New England Biolabs, Beverly, MA) between 12 and 16 hours at $37^{\circ} \mathrm{C}$ (overnight).

Electrophoresis was performed on 1\% agarose gel using $0.5 x$ Tris-borate-EDTA buffer with $50 \mu \mathrm{M}$ of thiourea in a Chef Mapper XA (BioRad Laboratories, Hercules, (A) at $6 \mathrm{~V} / \mathrm{cm}$ for $19 \mathrm{~h}$ at $14^{\circ} \mathrm{C}$ with an exchange time initially of $2 \mathrm{~min}$ and $16 \mathrm{~s}$ and a final change time of $63.8 \mathrm{~s}$. The gels were stained for $30 \mathrm{~min}$ at room temperature with ethidium bromide (Invitrogen ${ }^{\circledR}$, Carlsbad, CA), bleached and photographed. A strain of Salmonella enterica subspecie enterica serovar Braenderup (ATCC®BAA-664) was used as reference. Standard images were acquired using a Kodak Gel Logic 2200 system and analyzed using BioNumerics version 2.0 software (Applied Maths BVBA, SaintMartens-Latem-Belgium).

All $E$. coli isolates from water, meat and soil were used. However, only poultry litter from the farms that also had positivity in more than one type of substrate (water, soil and/or meat) were selected for PFGE analyses.

Using a coefficient of correlation, it was possible to determine the similarity between the profiles obtained in the gel. According to the technique of Carriço et al. (2005), for the analysis of PFGE patterns, a band position tolerance (divergence) of up to $1.7 \%$ was used. The dendrograms were generated by grouping of unweighted pairs with mathematical average (Unweighted Pairwise Grouping with Mathematical Averaging - UPGMA). In case the number and location of the bands were indistinguishable, the isolates were considered to belong to the same pulsotype.

\section{RESULTS}

Out of 228 samples collected (57 from each substrate), E. coli was isolated in 108 (47.4\% of the total), being 16 from water (14.8\%), 53 from litter $(49.1 \%), 15$ from soil $(13.9 \%)$ and 24 from chicken meat $(22.2 \%)$. Out of 24 positive samples of chicken meat, $4 / 17$ were obtained in gizzards $(23.5 \%), 3 / 15$ in hearts $(20 \%), 6 / 8$ in tulips (75\%) and $11 / 17$ in drumettes (64.7\%).

One $E$. coli isolated from soil (9S) and six of chicken meat (2M, 18M, 26M, 27M, 35M and 37M) were discarded due to bacterial contamination. Thus, $69 E$. 
coli isolates were tested (16 of water, 14 of soil, 21 of litter and 18 of chicken meat samples) using the PFGE technique. Out of these 69 samples, we were unable to obtain PFGE results from two litter samples (30C and $50 \mathrm{C}$ ) and two meat samples (16M and 19M) since they did not show defined band profiles despite the use of thiurea in the PFGE protocol.

The dendogram (Figure 1) of the $65 \mathrm{E}$. coli isolates showed 10 pairs of clones, each pair belonging to the same substrate as described in Table 1. No clones were found in the same property, and of the isolates, the highest correlation was $70.9 \%$ in two situations: one between the water and soil samples from property number 24 and the other between the litter and soil samples of property number 26 .

No clones were found in poultry litter. The samples that came closest were the $43 \mathrm{C}$ samples

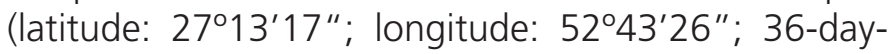
old flock; with eight consecutive flocks without total litter removal; collection date: 05/01/2018) and 48C

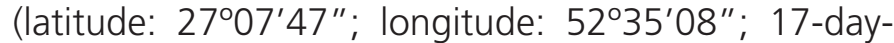
old flock; third consecutive flock housed without full litter removal; collection date: 05/01/2018) with $97.1 \%$ similarity and approximately $17.1 \mathrm{~km}$ of distance.

\section{DISCUSSION}

The presence of $E$. coli in poultry facilities is very common since it is a comensal bacterium present in the intestinal microbiota of animals and humans in addition to the fact that broiler chickens are raised on the floor. Mo et al. (2017) report that in broiler production it is likely that bacteria are present in suspension, on surfaces and occasionally in biofilms. Therefore, a high positivity for $E$. coli was expected in litter samples (over 90\%), but a little more positivity was expected in soil samples. This finding might be explained by the fact that not all soil samples were collected in places fertilized with animal waste or with animal transit.

Table 1 - Epidemiological profile of Escherichia coli identified as clones isolated from poultry.

\begin{tabular}{|c|c|c|}
\hline Clone pair & Sample ID & Features of samples \\
\hline \multirow{3}{*}{1} & $28 \mathrm{~A}$ & Coordinates (latitude: $26^{\circ} 58^{\prime} 20^{\prime \prime}$; longitude: 5249’31"); cistern water; collection date: 04/16/2018. \\
\hline & $35 \mathrm{~A}$ & 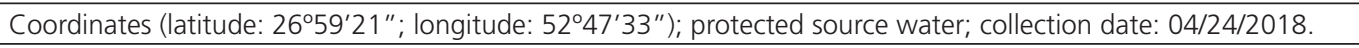 \\
\hline & \multicolumn{2}{|c|}{ Distance between the two points: $3756,310 \mathrm{~m}(3.7 \mathrm{~km})$} \\
\hline \multirow{3}{*}{2} & $51 \mathrm{~A}$ & Coordinates (latitude: $27^{\circ} 01^{\prime} 23^{\prime \prime} ;$ longitude: 52³2'01"); source water; collection date: 05/01/2018. \\
\hline & $52 \mathrm{~A}$ & Coordinates (latitude: $27^{\circ} 03^{\prime} 38^{\prime \prime}$; longitude: 52²3'46"); source water; collection date: 05/01/2018. \\
\hline & \multicolumn{2}{|c|}{ Distance between the two points: 4336.196 m (4.3 km) } \\
\hline \multirow{3}{*}{3} & $5 S$ & $\begin{array}{l}\left.\text { Coordinates (latitude: } 26^{\circ} 55^{\prime} 06^{\prime \prime} \text {; longitude: } 52^{\circ} 50^{\prime} 23^{\prime \prime}\right) \text {; plantation of manioc fertilized with silage discarded; } \\
\text { collection date: } 03 / 26 / 2018 .\end{array}$ \\
\hline & 225 & $\begin{array}{l}\text { Coordinates (latitude: } 26^{\circ} 56^{\prime} 07^{\prime \prime} \text {; longitude: } 52^{\circ} 49^{\prime} 01^{\prime \prime} \text { ); fertilized orchard with litter for } 1 \text { year, slurry for } 6 \text { months } \\
\text { and animal traffic; collection date: 04/03/2018. }\end{array}$ \\
\hline & \multicolumn{2}{|c|}{ Distance between the two points: $2939,615 \mathrm{~m}(2.9 \mathrm{~km})$} \\
\hline \multirow{3}{*}{4} & $25 S$ & $\begin{array}{l}\left.\text { Coordinates (latitude: } 26^{\circ} 59^{\prime} 44^{\prime \prime} \text {; longitude: } 52^{\circ} 53^{\prime} 25^{\prime \prime}\right) \text {; corn fertilized with litter there are about } 6 \text { months; } \\
\text { collection date: } 04 / 16 / 2018\end{array}$ \\
\hline & 265 & $\begin{array}{l}\text { Coordinates (latitude: } 26^{\circ} 59^{\prime} 47^{\prime \prime} \text {; longitude: 52 } 52^{\prime} 34^{\prime \prime} \text { ); fertilized orchard with silage discarded, sawdust and } \\
\text { litter; collection date: 04/16/2018. }\end{array}$ \\
\hline & \multicolumn{2}{|c|}{ Distance between the two points: $1409.184 \mathrm{~m}(1.4 \mathrm{~km})$} \\
\hline \multirow{3}{*}{5} & $36 \mathrm{~S}$ & $\begin{array}{l}\text { Coordinates (latitude: } 26^{\circ} 59^{\prime} 04^{\prime \prime} \text {; longitude: } 52^{\circ} 47^{\prime} 45^{\prime \prime} \text { ); fertilized vegetable garden with litter a month ago; } \\
\text { collection date: } 04 / 24 / 2018 \text {. }\end{array}$ \\
\hline & 495 & Coordinates (latitude: $27^{\circ} 38^{\prime} 57^{\prime \prime} ;$ longitude: 52²1'13"); unfertilized flowerbed; collection date: 05/01/2018. \\
\hline & \multicolumn{2}{|c|}{ Distance between the two points: $85547,050 \mathrm{~m}(85.5 \mathrm{~km})$} \\
\hline \multirow{2}{*}{6} & $9 \mathrm{M}$ & Tulip; lot slaughtered on 05/21/2018. \\
\hline & $11 \mathrm{M}$ & Drumette; lot slaughtered on 05/30/2018. \\
\hline \multirow{2}{*}{7} & $29 \mathrm{M}$ & Gizzard; lot slaughtered on 04/16/2018. \\
\hline & $34 \mathrm{M}$ & Drumette; lot slaughtered on 06/04/2018. \\
\hline \multirow{2}{*}{8} & $44 \mathrm{M}$ & Drumette; lot slaughtered on 07/10/2018. \\
\hline & $45 \mathrm{M}$ & Tulip; lot slaughtered on 07/10/2018. \\
\hline \multirow{2}{*}{9} & $48 \mathrm{M}$ & Heart; lot slaughtered on 06/20/2018. \\
\hline & $50 \mathrm{M}$ & Tulip; lot slaughtered on 07/03/2018. \\
\hline \multirow{2}{*}{10} & $51 \mathrm{M}$ & Gizzard; lot slaughtered on 06/15/2018. \\
\hline & $57 \mathrm{M}$ & Drumette; lot slaughtered on 07/19/2018. \\
\hline
\end{tabular}

The table shows 10 pairs of clones of Escherichia coli isolated from different points of the poultry production chain in the Southern of Brazil where "A" means water samples, "S" for soil and " $\mathrm{M}$ " for chicken meat. In the third column, farm geographical location, sample characteristics and collection dates. 


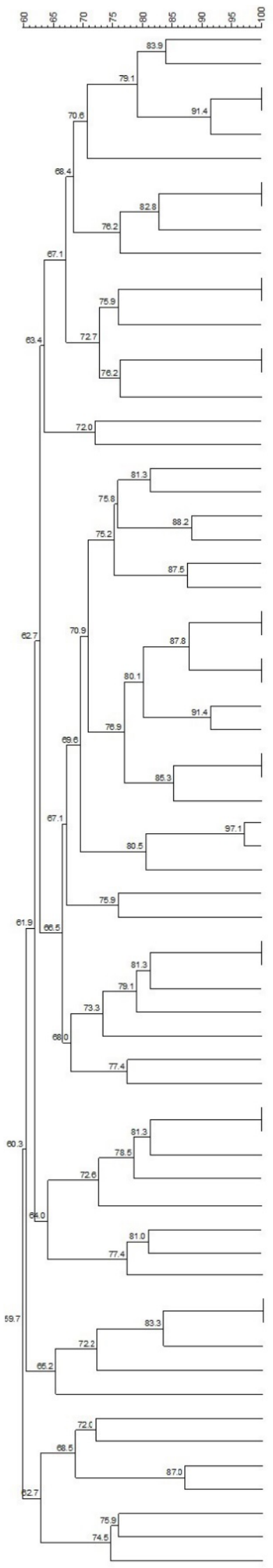

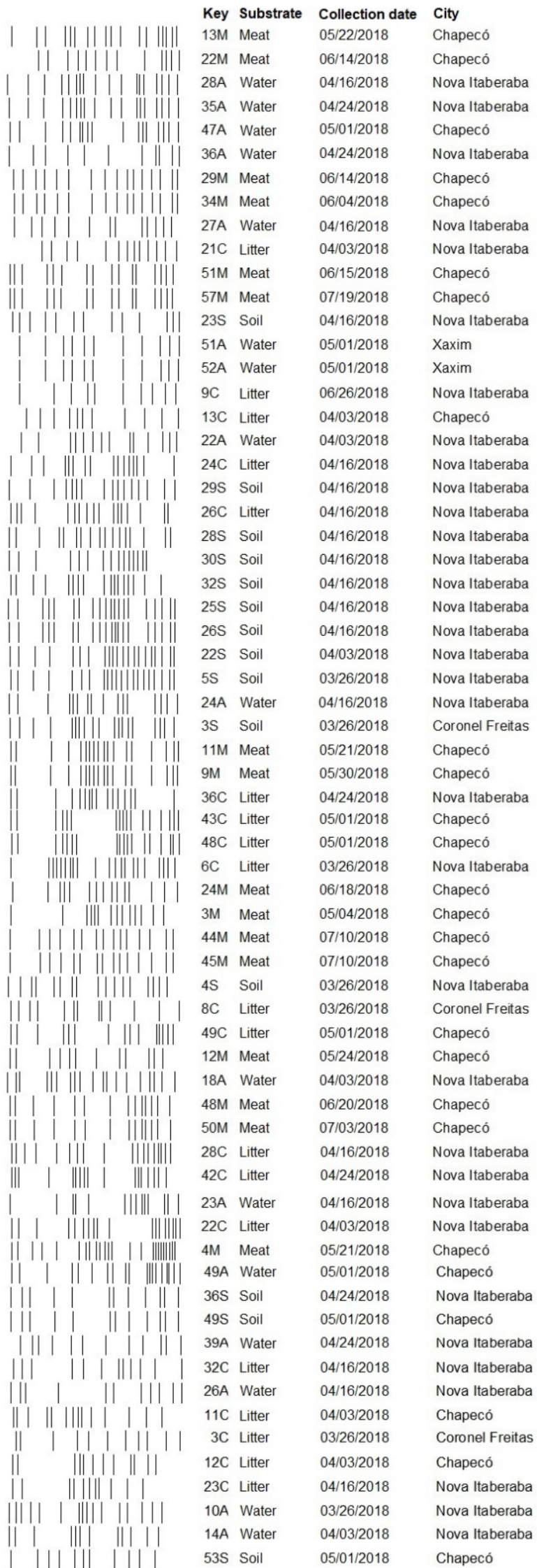

Figure 1 - Dendrogram after PFGE analysis of 65 Escherichia coli isolates colleted from the poultry production chain. The present dendogram shows the correlation between 65 strains of Escherichia coli using the Pulsed Field Gel Eletrophoresis technique with well-defined bands.
Thestudied regionischaracterized by a large number of small rural properties, very close to each other and with high animal density, which could predispose bacterial contamination of water sources. The water provided by cisterns comes from gutters on the roof of the poultry house and according to Silva et al. (2012) this type of water might be contaminated by E. coli. All water samples collected in this study were chlorine free used for poultry desedentation and showed $28.1 \%$ positivity indicating a need of chlorination before bird consumption.

Soil and water resources are directly related, especially in locations with high rainfall, which predispose the leaching of nutrients and microorganisms. In order to reduce the risk of fecal contamination of water sources on farms, animal waste used as fertilizers should be managed wisely and its nutritional content should be determined prior to application taking into account, climate and soil conditions, in addition to some characteristics of the plant that will be fertilized (Palhares et al., 2014).

Chicken meat samples were found to be positives for E. coli which is allowed by the Brazilian regulation agencies and this type of contamination may occur during the slaughter process more likely in the chiller. Geornaras et al. (1996) confirmed this hypothesis by stating that in poultry slaughterhouses, bacteria can contaminate equipments, water sources, air and handlers, resulting in cross contamination between carcasses. Out of all samples collected (32 from heart and gizzard), 21.9\% were positives for $E$. coli compared to $68 \%$ of chicken meat cuts ( 25 between drumette and tulip), this is probably due to the fact that the 
Teles PFS, Boiago MM, Frigo A, Rampazzo L, Araújo DN, Kich JD, Rebelatto R, Furian TQ, Stefani LM
Genetic Similarities of Escherichia Coli Isolated from Different Substrates of the Broiler Production Chain offalls go through a washing process. Ferreira et al. (2018), when evaluating some epidemiological studies suggested that high contamination of broiler carcasses is related to high levels of $E$. coli contamination, and thus, a source of EXPEC for humans.

The PFGE technique showed two pairs of clones in water, three pairs in soil and five pairs in chicken meat samples. The fact that no clones were found in litter may be due to the fact that this substrate contains a high log of $E$. coli as it is one of the main commensal bacteria of the digestive tract and a single pool was collected (three points) with only one colony isolated by cultivation. Boratto et al. (2004) reported that in one gram of broiler feces there may be $10^{6} \mathrm{CFU}$ of $E$. coli, reinforcing the hypothesis of the absence of clones.

Reeves et al. (2011) while studying a residence for three years, which also included a dog, reported that isolating a clone at a specific sampling point in successive events may not only be a clone persistence, but that members of the family are reinstating it. This suggests that if the present work were repeated in the same locations, there could be a large number of clones between the first and second collection cycles.

There was no record of the purchasing day of the meat samples, so it is unknown the day they were handled in the laboratory, just the day they were packed by the slaughterhouse. It is important to highlight that the five clones identified in meat were of different cuts, and only one of them coincided with the same day of packaging, suggesting that there is a strong persistence of the bacteria at the slaughterhouse, even when strict hygiene procedures are followed.

The fact that only clones were found within the same substrate type indicates that each type of $E$. coli has specific needs for its growth. Reeves et al. (2011), comment that the population structures of bacteria are different from those of more complex organisms, so that the low frequency of genetic recombination in relation to reproduction allows the growth of multiple clones adapted to specific niches, as there are several E. coli 0157:H7 clones causing hemolytic uremic syndrome.

\section{ACKNOWLEDGMENTS}

The authors thank for the financial support provided by the Foundation for Research, Education and Culture of the Santa Catarina State (FAPESC) and the National Council for Scientific and Technological Development (CNPq).

\section{REFERENCES}

ABPA. Estatísticas/desempenho de produção. Concórdia: Embrapa Suínos e Aves; 2018 [cited 2019 Jul 4]. Available from: www.embrapa.br/ suinos-e-aves/cias/estatisticas.

Boratto A, Lopes D, Oliveira R, Albino L, Sá L, Oliveira G. Uso de antibiótico, de probiótico e de homeopatia, em frangos de corte criados em ambiente de conforto, inoculados ou não com Escherichia coli. Revista Brasileira de Zootecnia 2004;33(6):1477-1485.

Camargo L, Suffredini I. Impacto causado por Escherichia coli na produção de animais de corte no Brasil: revisão de literatura. Journal of the Health Sciences Institute 2015;33(2):193-197.

Carriço, JA, Pinto FR, Simas C, Nunes S, Sousa NG, Frazão N, et al. Assessment of band-based similarity coefficients for automatic type and subtype classification of microbial isolates analyzed by pulsed-field gel electrophoresis. Journal of Clinical Microbiology 2005;43(11):54835490 .

CDC. Standard Operating Procedure for PulseNet PFGE of Escherichia coli 0157:H7, Escherichia coli non-O157(STEC), Salmonella serotypes, Shigella sonnei and Shigella flexneri. Atlanta: Centers of Disease Control and Prevention, 2017 [cited 2018 Jan19]. Available from: https://www.cdc.gov/pulsenet/pdf/ecoli-shigella-salmonella-pfgeprotocol-508c.pdf.

Downes $F$, Ito $K$. Compendium of methods for the microbiological examination of foods 2001. Washington: American Public Health Association; 2001

Ferreira J, Penha Filho R, Kuaye A, Andrade L, Chang Y, Darini A. Virulence potential of commensal multidrug resistant Escherichia coli isolated from poultry in Brazil. Infection, Genetics and Evolution 2018;65(11):251-256

Geornaras I, Jesus AE de, Zyl E van, Holy A van. Bacterial populations associated with poultry processing in a South African abattoir. Food Microbiology 1996;13(6):457-465.

Magalhães V, Ferreira J, Barelli C, Darini A. Eletroforese em campo pulsante em bacteriologia - uma revisão técnica. Revista Instituto Adolfo Lutz 2005;64(2):155-161.

Mo S, Sunde M, llag H, Langsrud S, Heir E. Transfer potential of plasmids conferring extended-spectrum-cephalosporin resistance in Escherichia coli from poultry. Applied and Environmental Microbiology 2017;83(12):e00654-17.

Palhares J, Kich J, Bessa M, Biesus L, Berno L, Triques N. Salmonella and antimicrobial resistance in an animal-based agriculture river system. Science of the Total Environment 2014;472:654-661

Quinn PJ, Markey BK, Cater ME, Donnely WJ, Leonard FC. Microbiologia veterinária e doenças infecciosas. Porto Alegre: Artmed; 2005.

Reeves P, Liu B, Zhou Z, Li D, Guo D, Ren Y, et al. Rates of mutation and host transmission for an Escherichia coli clone over 3 years. PlosOne 2011;6(10):e26907.

Ribot EM, Fair MA, Gautom R, Cameron DN, Hunter SB, Swaminathan B, ert al. Standardization of pulsed-field gel electrophoresis protocols for subtyping of Escherichia coli 0157:H7, Salmonella and Shigella for PulseNet. Foodborne Pathogens and Disease 2006;3(1):59-67.

Rwego I, Gillespie T, Isabirye-Basuta G, Goldberg, T. High rates of Escherichia coli transmission between livestock and humans in rural Uganda. Journal of Clinical Microbiology 2008;46(10):3187-3191. 
Silva, C. Heller L, Carneiro M. Cisternas para armazenamento de água de chuva e efeito na diarreia infantil:um estudo na área rural do semiárido de Minas Gerais. Engenharia Sanitária e Ambiental 2012;17(4):393400 .

Silva C, Neufeld P. Bateriologia e micologia para o laboratório clínico. Rio de Janeiro: Revinter; 2006.

Smith J. Superinfection drives virulence evolution in experimental population of bacteria and plasmids. Evolution 2010;65(3):831-840. 